\title{
EIGHTEEN YEARS \\ OF VESALIAN STUDIES
}

by

\author{
The late GHARLES SINGER
}

\begin{abstract}
Charles Singer, the distinguished historian of medicine, whose recent death has been such a blow to his many friends and colleagues, had long had a special interest in the history of anatomy and especially in Andreas Vesalius, the most celebrated figure in the long history of that subject. It was natural, therefore, that the appearance in 1959 of several books related directly and indirectly to Vesalius was of more than ordinary concern to him and, indeed, led to the organization of a Vesalian symposium at 'Kilmarth', his home in Cornwall, in October of the same year. It was as an aftermath of that occasion, which engendered an enthusiasm in Dr. Singer to be envied by those many years his junior, that he decided to write an extensive review of contributions to Vesalian literature since the appearance of Harvey Cushing's Bio-bibliography in 1943. Regrettably Dr. Singer did not live to complete his review, but the portion which he did write, representing as it does the mature judgment of the dean of medical historians, is much too important to be neglected. In consequence it is presented here as it was written. Since he had almost completed his remarks on Ruben Eriksson's edition and translation of Baldasar Heseler's notebook, it has been thought appropriate to complete that portion of the review with a surmise as to what the concluding words might have been.
\end{abstract}

Professor C. D. O'Malley has long been recognized as the greatest living authority on the life and work of Vesalius. He has recently published an introduction to a folio facsimile of the first scientific work on anatomy in English. ${ }^{1}$ It is commonly associated with the name of its publisher, Thomas Geminus, alias Lambrit, a Flemish engraver domiciled in England. The appearance of this work is the justification for this article.

As early as 1545 Geminus produced excellent copper plates of most of the woodcuts of Vesalius together with a Vesalian Latin text, which, however, does not apply to them. He reprinted the figures in I 553 with a more proper text, that is to say with most of their captions, Englished by the learned but disreputable Nicholas Udall ( $1505-56$ ) who had considerable literary skill but no knowledge of anatomy. These are the figures and this is the text luxuriously reproduced by O'Malley. All interested in medical history look forward to his definitive biography of Vesalius, his translation of the Fabrica as a whole and his bibliography of Vesaliana. It must necessarily be some years before these can appear. Meantime it may be useful to outline the history of recent Vesalian scholarship terminating with this last work. Only the more important works are here discussed for the writings on Vesalius are endless.

Everyone knows something of the achievement of Vesalius. It has been debated for four hundred years. His De humani corporis Fabrica, first printed at Basel in 1543 with a second edition in 1555 , has often been reprinted. Some of its figures, and especially its frontispiece, its skeletons and musclemen, and the 


\section{Eighteen Years of Vesalian Studies}

portrait of its author, are very familiar. The work was a great example of bookreproduction, a triumph of wood-engraving, and one of the most beautiful books of its century. It represented a real advance in the wood-engraver's art as well as in the knowledge of anatomy and is, moreover, basic to the history as well as to the practice of modern scientific medicine. Without Vesalius there would have been no Fabrizzi and no Harvey. The original work is an exhibitionpiece in many libraries, yet the personality and much of the circumstances of its author have remained something of mystery from the beginning.

Little concerning the career of Vesalius emerged into documented clarity until the publication by Moritz Roth (1839-1915) of Basel of his great book Andreas Vesalius Bruxellensis (1892). Yet even with this important research the character of Vesalius remained dim and seemed in many ways contradictory. Considering his immense influence on the course of medicine, and considering that he was from the first recognized as a very great authority on anatomy and was a professor in the most progressive university of his time, it is extraordinary that the man himself should have remained so elusive.

A new stage was reached with the Bio-bibliography started by Harvey Cushing (1869-1939). This was finished, seen through the press and published in New York, by Professor John Fulton who modestly omitted his own name from the title-page. Anyone who has access to this volume can find in it everything of importance on Vesalius published to 1943 . Here we need consider therefore only the more solid material that has appeared since. It may help the reader if we enumerate the works of Vesalius in a table associated with the major events of his life.

Vesalius was born 30 December 1514 near Brussels of a well-to-do family long associated with medicine and attached to the Imperial House. Anatomy was by then beginning as a separate science and the humanist scholars were hard at work 'purifying' the anatomical vocabulary from Arabic terms. Moreover, in I522 Berengario da Carpi published at Bologna his Isagogae breves Anatomicae, the first printed work on the subject that can be called illustrated. Some of its figures are not without beauty. They may have influenced the thought of Vesalius. An English translation of this work of Berengar has fortunately been made available by Professor L. R. Lind of the University of Kansas. ${ }^{2}$ (There was also a less complete one published in the seventeenth century.)

In 1528 Vesalius was at school at the medievally fashioned Pegagogium Castre at Louvain. In I53 I he transferred to the humanistic Collegium Trilingue at Louvain. There he became an expert Latinist and learnt Greek, his knowledge of which afterwards improved. He became a very fluent speaker of a highly stylized Latin, which was his literary medium. His knowledge of the third tongue of the trilingual college, Hebrew (or Arabic for he hardly distinguished between them since Arabic in the West was then printed in Hebrew letters) was, however, practically non-existent. When he used an Arabic or Hebrew word it is 'just for show'.

I533. To study medicine better Vesalius left for Paris where the serious study of anatomy in Galen's tradition had long been practised. Beginning from 1528 , 


\section{The late Charles Singer}

moreover, Galen's anatomical texts in Latin translations were being printed in Paris. He worked there with Guenther of Andernach, a good and very industrious translator of Greek medical works, and with Sylvius who was a much more practical anatomist as well as an excellent scholar. Vesalius undoubtedly profited greatly from both men, and his later allegation of having learned almost nothing from them must be treated as among the human infirmities of a great mind.

Vesalius did dissections for Guenther's Institutiones Anatomicae (I536), and he learned much practical anatomy as well as nomenclature from Sylvius. Dryander, Estienne and Servetus were all at Paris at the same time as Vesalius. Charles Estienne and Servetus did not influence him at all, and Estienne has not even been shown to have been in contact with him. Vesalius, who was a reasonably capable draughtsman, was making anatomical drawings in these years, and Dryander, afterwards professor at Marburg, copied or stole certain of them. Nevertheless we find Vesalius in $154^{\circ}$ praising certain of Dryander's representations of the brain.

I536. Vesalius was for a time in Louvain where he dissected his first female body and discovered the corpus luteum. Early in 1537 he made the first public dissection at Louvain for eighteen years. About this time he printed his Paraphrase of the Ninth Book of Rhazes to Almansor. It is a work of no importance and a mere 'hangover' from the scholastic period, though several times reprinted. For us its only significance is that it contains the suggestio falsi that its author understood Arabic. It cannot be a 'graduation thesis' but it is not above that level. Later in the year 1537 Vesalius migrated to the Venetian Republic. Early in December he was given the M.D. of Padua and became at once teacher of surgery at the Venetian University of Padua with the duty of including anatomy in his course. He gave his first series of anatomical demonstrations at Padua between 5 December and 26 December. Notes of these dissections survive and even several of the sketches that he then made, as was his wont.

In 1538 Vesalius printed at Venice the work known as his Tabulae anatomicae sex though it has no formal title. It consists of six unusually large folio leaves printed on one side only and surrounded by explanatory text. The first three figures were doubtless drawn by Vesalius himself. They set forth what he believed to be Galen's physiological system. They do this for the first time with any graphical clarity though they cannot be treated as accurate reflection of the thought of Galen. They omit any drawing of the nervous system, which was the department of anatomy in which Vesalius was weakest. The last three sheets are of skeletons only and are the work of Jan Calcar, a Flemish artist who, at that time, was also in Venice. Calcar seems to have been considerably older than his colleague. Their joint work was printed, according to the colophon, 'at Calcar's expense'. This may mean that Calcar took the profits and that it was a way of paying him. These drawings by Calcar are no better than mediocre and have something slightly comic about them. In any event there is no good reason to associate Calcar with Vesalius in any other publication and certainly not with the magnificent skeletons of the Fabrica. The text of the Tabulae sex 


\section{Eighteen Years of Vesalian Studies}

has been translated into English with running commentary by Professor Rabin and myself, under the title $A$ Prelude to Modern Science. ${ }^{8}$

The Tabulae sex recall a convention of the age for providing medical students with the little anatomical and physiological knowledge then demanded of them. Several contemporaries of Vesalius produced comparable sheets to be hung on a wall by the student and glanced at as he read his (usually Galenic) text. In this case there can be little doubt of the text suggested, since, a few weeks after the Tabulae sex, Vesalius issued at Venice his own revision of Guenther's Institutiones anatomicae which expounds an essentially Galenic physiology.

In I 539 Vesalius issued at Basel his so-called Blood-letting Letter. This work is of no value for the history of science. It depends on a wholly mistaken view of the function and action of the veins. It recalls a controversy that became pointless as soon as Harvey's views were appreciated. Nevertheless it contains some details concerning the personal contacts of Vesalius. Thus its translation into English with introduction by Professors J. B. de G. M. Saunders and C. D. O'Malley is one of the most fruitful of Vesaliana published during recent years. ${ }^{4}$

January 1540. Despite the suggestion of intensive practical teaching given by the over-crowded scene of the Fabrica frontispiece, references by his pupils to Vesalius are conspicuously rare. Roth, after long search, found only a 'memo' by one such student to which we have already referred, and $O^{\prime}$ Malley has since published and interpreted this student's copies of the drawings of Vesalius. ${ }^{5}$ Even this leaves Vesalius in no more than a teacher's capacity and tells nothing about the man. But in 1959 we were, at last, able to meet him face to face, though still not in a close-up. Dr. Ruben Eriksson of Stockholm found there a manuscript notebook by a German student at Bologna where Vesalius was then living. These notes give a vivid picture of him over one short course of lecture-demonstrations. ${ }^{6}$ We quote the student's own introduction to his own notebook.

A course of lectures on the anatomy of Mundinus-in his days the most outstanding of physicians - given at Bologna by D. Matthaeus Curtius, during which he corrected many errors according to the doctrine of Galen. The anatomist of Curtius was D. Andreas Vesalius from Brussels, a 'German' by birth, the most skilled of anatomists. He was called by us students and came here to Bologna [which was a 'students' university, not a 'professors'], especially for the 'German' students. Partly after Galen, partly through his own discoveries he corrected many false opinions by dissection of three human bodies and six dogs and other animals, and showed us many things neither heard nor seen before. I Baldasar Heseler [1508-67], student of medicine, have written down what I could of this whole course.

At this time Vesalius must have begun his work on the Fabrica.

The twenty-six demonstrations of Vesalius were given alternatively with the lectures of Curtius (Corti 1475-1542), a good but conservative scholar completely attached to the texts of Galen and of Mundinus. His posthumous edition of Mundinus (Pavia, I550) is the best of the thirty or so that I have examined. (The text of Mundinus is available in an English translation by me incorporated in my edition of the 1493 edition of the Fascicolo di Medicina, ${ }^{7}$ better but wrongly 


\section{The late Charles Singer}

known as Ketham.) The demonstrations of young Vesalius thus set out by the side of the lectures of old Curtius provide an almost unhoped for contrast between medieval anatomy and the dawn of the modern science. This gives Dr. Eriksson's well presented book a special value since modern medicine is necessarily based on anatomy. Heseler's notes both for demonstrations and lectures were turned into a fair copy each evening while fresh in his mind.

Opening the first demonstration, Vesalius made an error that he recalls in the Fabrica. He asserted that the rectus abdominis muscle extends upwards to the clavicle. This it does in the monkey as recorded in Galen On Anatomical Procedures, ${ }^{8}$ the Latin translation of which Vesalius was then revising for the Giunta Opera omnia Galeni. In his account of the same demonstrator Heseler tells us that there was, as throughout, always a skeleton on the table. The account of the fifth demonstration deserves special study. In it Vesalius repeatedly told the students to read Galen, and during his dissection of the jaw muscles he said that certain Galenic passages had been wrongly translated. It would be profitable to compare this passage in the Giunta edition to that in Guenther's.

From the account of the sixth demonstration we learn that Vesalius was wont to sketch with charcoal on the dissection table and that throughout he paid special attention to the muscles. These structures had been neglected by his contemporaries except, of course, the artists. As might be foreseen the weakest accounts by. Vesalius were that on the nervous system and that on the female genital organs. For the latter he had no human example and demonstrated on a pregnant bitch. He committed himself to the medieval view that in the right horn male pups are conceived because it is warmer by nearness to the liver, while in that on the left are the females. Vesalius repeated several other medieval errors on the relation of the foetus to the mother.

The fifteenth demonstration of Vesalius is on the brain. Book VII of the Fabrica is mostly devoted to that subject and is the only one at present available in English. As anatomy it is perhaps the worst of the seven books of the Fabrica but to see it in its true light we must await Dr. O'Malley's translation of the complete work. I have provided a provisional English version.'

We give Heseler's account in abbreviated form.

This afternoon he did the anatomy of the head, brain, its ventricles, seven pairs of cranial nerves and all its parts. To ensure better understanding he first spoke at length on Galen's De anatomicis administrationibus, IX. He asked us also to look at the picture of the anatomy of the head, printed [by Dryander, afterwards a bugbear of Vesalius] in Marburg, which certainly very much contributed to the knowledge of the brain. [I have reproduced Dryander's figures]. ${ }^{10}$ Making an incision he showed us the pericranium, a membrane covering the cranium. After we had seen this, he took off and showed us the section of the cranium which he had severed. The whole substance of the brain then appeared to us. And first he showed us the dura mater. It envelops the whole brain, and also divides it into right and left. On its surface were veins and arteries nourishing it. Then beginning in the occiput he cut it straight to the sinciput. Next we saw the pia mater, in which veins and arteries were inserted and on the inner surface [of the dura] there were so-to-say ducts and small cells so that [the veins and arteries] could yield upwards according to the movement of the whole brain. For he showed us that the substance of the brain moves [which it does not] and before opening the dura he pierced it and, 


\section{Eighteen Years of Vesalian Studies}

inserting a quill, inflated it. It rose sufficiently for the dilatation of the brain. Between the two halves of the brain he showed us a sinus [torcular] through which the veins and the arteries at each side of the neck passed upwards into the substance of the brain. Then he removed the pia mater, a very subtle membrane which closely covers the brain. We saw how in the surface of the brain there were various smooth convolutions.

Next, before he cut into the ventricles, he showed them on the head of a sheep, in which we could see them better. Inserting the fingers of one hand through the partition of the brain he slightly lifted one part of it and in the front showed us the first ventricle which was like a narrow cavity and as a channel or passage to another duct. Then in the same manner he showed us the second [-third] and middle ventricle. This led deep into the substance of the brain. In the cerebellum itself, when separated from the front part of the brain, he showed us a third [-fourth] ventricle. Thus, the middle ventricle was like a passage from the front to the back of the brain. In the back part [-cerebellum] he also showed us some substance of the brain like a worm. He put it on a paper; it was white and had the form of the great white worms that grow in wood [a simile used by Galen]. Under the mass of the brain he showed us some white callous substance [corpus callosum] to which go the superfluous fluids of the brain. At each side cavities go down, through which he said the superfluous fluids pass to their common receptacle, close to the palate and the nostrils. [A gross anatomical error-apart from its false physiology-based on Galen.] After we had seen this he lifted the substance of the brain higher, proceeding to the seven pairs of nerves. He showed the first pair that runs from the brain to the nostrils, and there the true instrument of smell, namely two nerves near the orifices in the cranium from the nostrils. Next he showed us another pair of nerves going to the eyes. They were large, white and in-curved. Through them the spiritus visivi pass into the eyes. And, he said, you see that the nerves are not crossed as some authors hold. Yet they are joined in the middle, broadening there, but the right nerve goes to the right eye, and the left to the left eye, which can be proved, if a pen be inserted between them. Near them another pair runs to the ears. Near them again he showed us another pair that go to the eyes to make them move. He showed us the sixth pair going to the chest [vagus] and the seventh to the tongue. And he did not tell us their order, which you can see in books on anatomy, because he was very confused, owing to the noise and disorder of the students. [In fact Vesalius, even in his great book, is so confused as to the origin of the cranial nerves that he is beyond interpretation.] Therefore being upset, as he was very choleric, he hurried on this dissection to get through it anyhow. Eventually, he showed us the network of arteries around the rete mirabile in which the spiritus animales are produced, transmitted there from the heart as spiritus vitales. And I saw particularly those which run in coils around the base of the cranium which are called rete mirabile. [This must have been in an animal as there is no rete in man.]

Vesalius demonstrated the cranial nerves again in a later demonstration as confused as he is in the Fabrica itself.

The sixteenth demonstration was on the abdominal organs. We quote from it only insofar as it reveals something of the circumstances of dissection of the time.

This morning when we had come to the anatomy, D. Vesalius complained that someone had taken the better subject to dissect. Thus it is now worthless but we shall at least see in it the three venters. If we had had the other, I should have shown you the anatomy of the arteries. But the Rector had arranged that servants from the Ospedale alla morte [mortuary chapel] immediately brought this body in a piece of cloth back to us. But the dissection had already begun and how they derided the wretch. First, Vesalius said, you see here the dissection of the musculi recti abdominis, that he has nearly cut and left in the abdomen. Secondly, this dissector wanted to see the musculi transveri abdominis, but could not find their sinew. Thirdly, he has hashed the abdomen, as the intestines are falling out. Fourth, he has been kind enough to sever the left artery leading to the left spermatic vessels. Again he had not severed the fleshy muscle 


\section{The late Charles Singer}

from the double skin but, like the butchers, has removed them together with other mistakes of those eminent dissectors. All laughed heartily at this 'anatomicus'!

For the seventeenth, as in some other demonstration, he used his Tabulae. He repeated observations on the differences in distribution of genital bloodvessels on the two sides. In the Fabrica the very bad section on the sex organs shows that in 1543 he continued to entertain his errors on parallelism of the male and female organs.

In the twenty-second demonstration Vesalius appeared at his most natural. We therefore quote him, though his dispute with Curtius as to the side one should bleed in pleurisy, is an empty topic.

The lecture of Curtius being ended, Vesalius, who had heard the contradiction of his arguments, asked Curtius to join him at the dissection. Bringing him to our two bodies he said: 'See whether I have made an error. Meantime leave Galen for, if I may say so, here he errs, being ignorant of the distribution of the azygos vein which is the same now as then.' Curtius answered smiling, for Vesalius, choleric as he was, was very excited: 'No, Domine, we must not leave Galen, for he always understood aright. Can you interpret Hippocrates better than he?' Vesalius answered: 'I do not say so, but I show you in these bodies how the azygos vein nourishes all the ribs except the two upper wherein is no pleurisy. For always here'-he knocked against the middle of the chest-'occurs inflammation and pleurisy, not at the two upper ribs. Consequently, as this vein also is distant from the heart, as you see, by three fingers' breadth, it will always in pleurisy be better to bleed from this vein only and it matters not whereabouts since these ribs are nourished exclusively by it.' Curtius replied: 'I am no anatomist, but there may be other veins nourishing the ribs and the muscles besides these.' 'Where please?' Vesalius said, 'show them to me.' Curtius said: 'Do you want to deny Nature's own ducts?' 'Oh', answered Vesalius, 'you would discuss things invisible. I speak of the visible.' Curtius responded: 'Indeed, I always deal with the evident. Domine, you wrongly understand Hippocrates and Galen on this.' Vesalius retorted: 'So be it, for I am not as old as you.' Thus with much quarrelling and scoffing they attacked each other and got nowhere. Vesalius said: 'Domine, I beg Your Excellency not to think me so unskilled that I do not know and understand this.' Smiling Curtius said: 'Domine, I did not say so. I have said that you are excellent, but I have reflected the explanation implying that Galen could have erred.' Vesalius replied: 'I have said that Galen has erred and this is evident here in these bodies.'

Equally illustrative of the futility of these discussions is a section of the twentyfourth demonstration.

D. Vesalius brought us the larynx of an ox from which he had cut various parts. 'For', he said, 'in the hanged subject we cannot see the larynges for they are destroyed by the noose, but they are quite different [in man and in animals]. Particularly in their cartilaginous organs we should mark the origin of the parts round which the muscles are inserted, as we did for other muscles of the body, where we always first reviewed the anatomy of the bones. Thus, first, he said, the larynx consists of three cartilages, as you have heard today from Curtius in his lecture: one is shield-like or scutalis and this we feel protruding in front of the neck. And he showed it to us in the larynx of an ox. But it is different in man, where it is not so long. The second cartilage has no name, and it lies higher in the back part of the larynx towards the gullet' [arytenoid]. Here Curtius said that it is the first if you begin from below and behind. Vesalius said that this was of little consequence. The third, he said, called arytenoid, is in the middle and has the form of a vessel from which we pour water for great men to wash their hands. And he showed us very clearly the composition and the function of each of the cartilages. 


\section{Eighteen Years of Vesalian Studies}

Then, inside below the arytenoid cartilage there are the vocal cords which are the proper instrument of the voice at each side consisting of a cartilaginous adipose membrane. At this instant Curtius who too superstitiously observed the terms said: 'No, Domine, the vocal cords are composed of a substance of adipose membrance only and not of a cartilaginous one.' Then Vesalius, a little excited, said: 'You don't maintain, Domine, that cartilage is fat?' Curtius said that that was Galen's opinion. 'Oh', Vesalius said, 'much is erroneously translated from Galen; thus where they ought to have written glottis, i.e. the vocal cords, they have put epiglottis, and vice-versa. Curtius answered: 'Oh, we can settle this from a Greek copy.' Vesalius said: 'But Greek manuscripts are also corrupt on this, but we have one at St. Mark's in Venice, very old and good, which now is translated, as you soon will see when it is printed.' [Vesalius had himself used it.] As it was nearly four o'clock Curtius left. Then Vesalius said: 'When we have understood the workings of the vocal cords, we may call them what you will, for I will not fight about words.' Then he showed us the vocal cords which were truly adipose.

Had Dr. Singer been permitted to complete his remarks, he would no doubt have called attention to the statement in the twenty-fifth demonstration, also on the brain: '[Vesalius] first showed us at each side the net-like plexus of the arteries which ascend from the rete mirable, and in which the spiritus animales are produced, and sent to the cavities of the brain'. In his edition of the Tabulae anatomicae sex, mentioned above, Dr. Singer called attention to the fact that Vesalius in 1538 still accepted the existence of this rete as fact, although later in the Fabrica he admitted his stupidity in having done so. We now learn from Heseler's words that Vesalius was in bondage to this Galenical error as late as the opening of 1540 .

In the twenty-sixth demonstration attention quite possibly would have been called to Vesalius's experiment in vivisection when, as Heseler writes, he severed the recurrent nerve of a dog. It was an experiment to be mentioned later in the Fabrica and to be repeated still later by Vesalius's pupil Realdo Colombo who presented it as his own. According to Heseler, after demonstrating how the procedure silenced the dog, Vesalius remarked:

I shall proceed to the heart, so that you shall see its movement, and feel its warmth, thirdly so that you shall here around the ilium feel the pulse with one hand, and with the other the movement of the heart. And please, tell me, what its movement is, whether the arteries are compressed when the heart is dilated, or whether they in the same time also have the same movement as the heart ... some students asked Vesalius what the true fact about the movements was, what he himself thought, whether the arteries followed the movement of the heart, or whether they had a movement different from that of the heart. Vesalius answered: I do not want to give my opinion, please do feel yourselves with your own hands and trust them. He was said always to be so little communicative.

Here Dr. Singer would no doubt have called attention to Vesalius's statement in the Blood-letting Letter of 1539 in which Vesalius wrote:

The motions of the heart and arteries are contradictory and contrary. To a certain extent this can be put to the test by the dissection of living animals if one hand is applied to the artery lying on the sacrum and the other grasps the whole of the intact heart.

Hence was Vesalius really, as Heseler writes, 'so little communicative' or was he, as a good teacher, attempting to make his students observe for themselves. 


\section{The late Charles Singer}

Despite those aspects of Vesalius's personality on which Heseler's remarks shed some light, the enigma of Vesalius has been only partially removed.

\section{NOTES}

I. Grminus, Thomas. Compendiosa totius anatomie delineatio. A facsimile of the first English Edition of 1553 in the version of Nicholas Udall. With an introduction. London, Dawson's, 1959.

2. A Short Introduction to Anatomy (Isagogae breves). Translated with an introduction and historical notes by L. R. LIND and with anatomical notes by PAUL G. Roore. Chicago, Univ. of Chicago Press, 1959.

3. A Prelude to Modern Science: being a discussion of the history, sources and circumstances of the Tabulac anatomicae sex of Vesalius. Cambridge, University Press, 1946.

4. The Blood-letting Letter of 1539. An annotated translation and study of the evolution of Vesalius's scientific development. New York, Schuman, 1946.

5. 'Anatomical sketches of Vitus Tritonius Athesinus and their relationship to Vesalius's Tabulae anatomicae.' J. Hist. Med., 1958, xm: 395-7.

6. Andreas Vesalius' First Public Anatomy at Bologna, 1540. An eyewitness report by BALDAsAR Hese Le R together with his notes on Matthaeus Curtius's lectures on Anatomia Mundini. Edited with introduction and translation into English and notes. Uppsala, Almquist and Wilksells, 1959.

7. Fasciculo di Medicina, Venice, 1493. With an introduction. Florence Lier, 1925, 2 vols.

8. Galen. On Anatomical Procedures ... De anatomicis administrationibus. Translation of the surviving books with introduction and notes. London, Oxford University Press, 1956.

9. Vesalius on the Human Brain. Introduction, translation of text, translation of descriptions of figures, notes to the translations, figures. London, Oxford University Press, 1952.

10. 'Brain Dissection before Vesalius', 7. Hist. Med., 1956, I, 261-74.

BIBLIOGRAPHY OF REFERENCES ON ANDREAS VESALIUS, 1943-1953

Benjamin, J. A. Discussion of 21 ist illustration of $5^{\text {th }}$ book of 'De Humani Corporis Fabrica' (1543). Bull. Hist. Med., 1943, xav, 634-51.

Cassirer, E. A. 'Place of Vesalius in the culture of the Renaissance.' Yale F. Biol. Med., 1943, XVI, 109-20.

Castiglioni, A. 'Andreas Vesalius, professor at the Medical School of Padua.' Bull. N.r. Acad. Med.; 1943, xix, 766-77.

Castiglioni, A. 'The attack of Franciscus Puteus on Andreas Vesalius and defence by Gabriel Cuneus.' Tale 7. Biol. Med., 1943, xv1, 135-48.

Gastiglioni, A. 'Three pathfinders of science in the Renaissance (Vesalius, Copernicus and Fracastorius).' Bull. med. Libr. Ass., 1943, xxxr, 203-7.

Gastiglioni, A. 'Vesalius and the "Fabrica", 1543-1943.' F. Amer. med. Ass., 1943, cxxxxi, $582-4$.

Codellas, P. S. 'Vesalius-Valverde-Patousas'; unpublished manuscript of first modern anatomy in Greek language. Bull. Hist. Med., 1943, xrv, 688-702.

Edelstein, L. 'Andreas Vesalius, the humanist.' Bull. Hist. Med., 1943, Xrv, 547-61.

Fisch, M. H. Printer of Vesalius's 'Fabrica'. Bull. med. Libr. Ass., 1943, xxxx, 240-59.

Francis, H. S. Woodcut initials of the 'Fabrica'. Bull. med. Libr. Ass., 1943, xxxr, 228-39.

Fulton, J. F. Celebration of 400 th anniversary of 'De Humani Corporis Fabrica' of Andreas Vesalius; introduction. Yale F. Biol. Med., 1943, xvi, 105-8.

Jones, T. Artists of Vesalius's 'Fabrica'. Bull. med. Libr. Ass., 1943, xxxI, 222-7. 


\section{Eighteen Years of Vesalian Studies}

Meyer, A. W. and Wirt, S. K. Amuscan illustrations (compared with Vesalian). Bull. Hist. Med., 1943, Xrv, 667-87.

O’Malley, C. D. and Sa unders, J. B. de C. M. 'Vesalius as clinician.' Bull. Hist. Med., 1943, XIv, $594-608$.

Rollins, C. P. Oporinus (Johann Herbst) and publication of the 'Fabrica'. Yale F. Biol. Med., 1943, xvi, 129-34.

SA Unders, J. B. de C. M. Vesalius and Don Carlos; historical footnote. Essays in Biology in Honor of Herbert M. Evans. Berkeley: University of California Press. 1943. pp. 529-38.

Sigerist, H. E. Albanus Torinus and German edition of the 'Epitome' of Vesalius. Bull. Hist. Med., 1943, XIv, 652-66.

Sigerist, H. E. 'Commemorating Andreas Vesalius'. Bull. Hist. Med., 1943, xIV, 541-6.

Singer, Gharles. 'To Vesalius on the fourth centenary of his "De humani corporis fabrica".' 7. Anat. (Lond.), 1943, LXXVI, 261-5. Illus.

Strauss, W. L., Jr. and Temxin, O. 'Vesalius and the problem of variability.' Bull. Hist. Med., 1943, XIv, 6o9-33.

Streeter, E. G. 'Vesalius at Paris.' Yale F. Biol. Med., 1943, xVI, 121-8.

Van Driessghe, A. 'Levensverhaal van Andreas Vesalius.' Verh. kon. Acad. Geneesk. Belg., 1943, V, 212-29.

Vesalius, ANDreas. The four hundredth anniversary celebration of the 'De humani corporis fabrica' of A. Vesalius. [Yale Med. Lib. Hist. Lib. Publ. No. 7.] front., (port.). pp. 67. [New Haven (Conn.):] Yale Univ. Med. 1943.

Zirbo org, G. 'Psychological sidelights on Andreas Vesalius.' Bull. Hist. Med., 1943, xiv, $562-75$.

Fische R, H. Erinnerung an Vesal (1514-64). Gesnerus (Aarau), 1944, 1, 115.

Wolf-Heidegger, Gerhard. 'Vesals Basler Skeletpräparat aus dem Jahre 1543. Verh. naturforsch. Ges. Basel, 1944, LV, 21 I-34. Illus., bibliog.

Calcar, Wesel and Vesalius. Brit. med. 7., 1945, 1, $381-2$.

ANSON, BARRY J. The initial letters of 1555 edition of Vesalius's 'Fabrica'. Quart. Bull. Northro. Univ. med. Sch., 1945, xIx, 326-35. Illus.

Frsch, M. H. 'Vesalius in English state papers.' Bull. med. Libr. Ass., 1945, xxxiI, $231-53$.

Franco, S. 'Andreas Vesalius and the Jews.' Harefuah, 1945, xxvm, 269.

Singer, C. 'Vesalian Problems.' Bull. Hist. Med., 1945, xvII, 425-38.

Wolf-Heidegger, Gerhard. 'Uber Vesals Aufenthalt in Basel im Jahre 1547.' Gesnerus (Aarau), 1945, II, 207-12. Bibliog.

Etziony, Morde caI. 'The Hebrew-Aramaic element in Vesalius; a critical analysis.' Bull. Hist. Med., 1946, xx, 36-57. Bibliog.

Hintzsche, E. 'Andreas Vesal und sein Werk.' Ciba Z., 1946, xx, 3655-62.

Hintzsche, E. 'Der Kampf um die vesalische Anatomie.' Ciba Z., 1946, Ix, 3663-73.

SAUnders, J. B. de G. M. and O'MALLEY, G. D. The preparations of the human skeleton by Andreas Vesalius of Brussels; an annotated translation of the 39th chapter of the 'De humani corporis fabrica', 1543. Bull. Hist. Med., 1946, xx, 433-60.

Sin GER, C. 'Some Galenic and animal sources of Vesalius.' F. Hist. Med., 1946, r, 6-24. Illus.

SINGER, G. J. and RABIN, G. B. A prelude to modern science: being a discussion of the history, sources and circumstances of the 'Tabulae anatomicae sex' of Vesalius [with a facsimile]. [Wellcome Hist. Med. Mus. Publications, New Ser. I]. Cambridge: U.P. 1946.

Singer, GHARLes. A word on the philosophic background of Vesalius. In: Studies and Essays in the History of Science and Learning offered in homage to George Sarton. . . . New York: Schuman. [1946.] pp. 75-84.

Argie ri, G. P. 'Leonardo da Vinci e Andrea Vesalio negli studi anatomici. Perchè Vesalio non può chiamarsi il padre dell' anatomia.' Riv. Stor. Sci. med., 1947, xxxvII, 182-215.

Vesalius, Andreas. Andreas Vesalius Bruxellensis: the bloodletting letter of 1539 . An annotated translation and study of the evolution of Vesalius's scientific development. By J. B. de C. M. Saunders and C. D. O’Malley. New York: Schuman. [1947.] 


\section{The late Charles Singer}

O'Malley, C. D. and SAunders, J. B. de C. M. The relation of Andreas Vesalius on the death of Henry II of France. 7. Hist. Med., 1948, m, 197-2 13. Port.

Anson, B. J. Anatomic tabulae and initial letters in Vesalius's 'Fabrica' and in imitative works. Surg. Gynec. Obstet., 1949, LXxxix, 97-120.

Paramore, R. H. Vesalius: anatomist (1514-64). 'Tabulae Anatomicae sex.' Brit. med. Bull., 1949, VI, 230-I.

Vesalius, ANDReas. 'The epitome of Andreas Vesalius.' Translated from the Latin with preface and introduction by L. R. Lind. With anatomical notes by C. A. Asling and a foreword by Logan Clendening. New York: Macmillan. 1949.

Artelt, Walter. 'Das Titelbild zur "Fabrica" Vesals und seine kunstgeschichtlichen Voraussetzungen.' Centaurus, 1950, 1, 66-77. Illus.

Furton, J. F. Vesalius four centuries later. ... [Logan Clendening lectures on the history and philosophy of medicine. Ist ser. I ... ]. Lawrence, Kansas: Univ. of Kansas. 1950.

SAUnders, J. B. de G. M. and O'MALley, G. D. The illustrations from the works of Andreas Vesalius of Brussels, with annotation and translations, a discussion of the plates and their background, authorship and influence, and a biographical sketch of Vesalius. Cleveland: World Pub. Co. [1950.]

Vesalius, ANDreas. [Russian translation of De humani corporis fabrica libri septem. Translated by V. N. Ternovskii and S. P. Shestakov. Edited by V. N. Ternovski. Epilogue by I. P. Pavlov] Tom I. Moscow: Akad Nauk. SSSR. 1950.

Fitzgibion, G. M. P. 'Anatomy Transformed: study of Andreas Vesalius and his work.' Irish F. med. Sci., 1951, April, 166-82.

Herrlinger, R. 'Das Schicksal der hölzernen Druckstöcke zu Vesals anatomischen Lehrbuch.' Münch. med. Wschr., 1951, xam, 613-16.

O' MAL L e Y, C. D. 'Life and Times of Andreas Vesalius.' Ann. west. Med. Surg., 1951, v, 191-8.

Anson, B. J. 'De humani corporis fabrica libri septem of Andreas Vesalius': title page, anatomical plates and initial letters. Anat. Rec., 1952, CxIv, 293-33I.

Monteiro, H. 'L'ancienne technique de préparation des os. A propos des lettrines de la "Fabrica" de Vésale.' Acta anat., 1952, xrv, 358-64.

Ollerenshaw, Robert. The decorated woodcut initials of Vesalius's 'Fabrica'. Med. biol. Ill., 1952, I, 160-6.

Russe L1, K. F. Andreas Vesalius and his 'Fabrica'. Aust. N.Z. F. Surgery, 1952, xxi, 300-3. Illus.

Vesalius, ANDReas. 'Vesalius on the Human Brain': introduction, translation ... notes . . . [by] C. Singer. [Wellcome Hist. Med. Mus. Publications. New Ser. 4.] London: O.U.P. 1952.

A Vesalian letter [written in 1588 to Prince of Orange; copy in Cushing collection at Yale]. 7. Hist. Med., 1953, vin, 448. Facsim. 